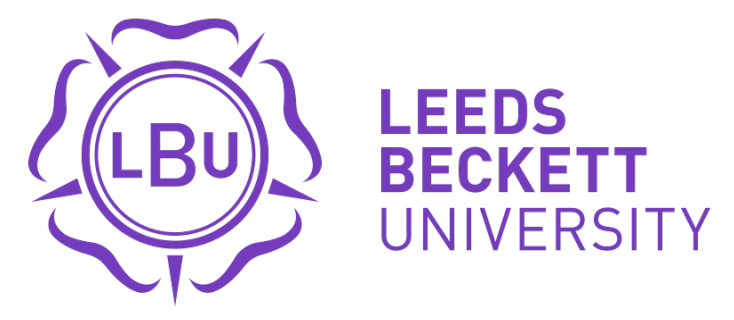

Citation:

Ajayi, SO and Oyedele, LO and Bilal, M and Akinade, OO and Alaka, HA and Owolabi, HA (2017) Critical management practices influencing on-site waste minimization in construction projects. Waste Management, 59. pp. 330-339. ISSN 0956-053X DOI: https://doi.org/10.1016/j.wasman.2016.10.040

Link to Leeds Beckett Repository record:

https://eprints.leedsbeckett.ac.uk/id/eprint/3437/

Document Version:

Article (Accepted Version)

Creative Commons: Attribution-Noncommercial-No Derivative Works 4.0

The aim of the Leeds Beckett Repository is to provide open access to our research, as required by funder policies and permitted by publishers and copyright law.

The Leeds Beckett repository holds a wide range of publications, each of which has been checked for copyright and the relevant embargo period has been applied by the Research Services team.

We operate on a standard take-down policy. If you are the author or publisher of an output and you would like it removed from the repository, please contact us and we will investigate on a case-by-case basis.

Each thesis in the repository has been cleared where necessary by the author for third party copyright. If you would like a thesis to be removed from the repository or believe there is an issue with copyright, please contact us on openaccess@leedsbeckett.ac.uk and we will investigate on a case-by-case basis. 


\title{
Critical Management Practices Influencing On-site Waste Minimization in Construction Projects
}

\begin{abstract}
As a result of increasing recognition of effective site management as the strategic approach for achieving the required performance in construction projects, this study seeks to identify the key site management practices that are requisite for construction waste minimization. A mixed methods approach, involving field study and survey research were used as means of data collection. After confirmation of construct validity and reliability of scale, data analysis was carried out through a combination of Kruskal-Wallis test, descriptive statistics and exploratory factor analysis.
\end{abstract}

The study suggests that site management functions could significantly reduce waste generation through strict adherence to project drawings, and by ensuring fewer or no design changes during construction process. Provision of waste skips for specific materials and maximisation of on-site reuse of materials are also found to be among the key factors for engendering waste minimization. The result of factor analysis suggests four factors underlying on-site waste management practices with $96.093 \%$ of total variance. These measures include contractual provisions for waste minimization, waste segregation, maximisation of materials reuse and effective logistic management. Strategies through which each of the underlying measures could be achieved are further discussed in the paper. Findings of this study would assist construction site managers and other site operatives in reducing waste generated by construction activities.

Keywords: Site management; waste management; contract management; materials reuse; logistic management. 


\section{Introduction}

Effective site management is increasingly recognised as the strategic approach for achieving the required performance in construction projects (Forster, 2014). This is due to the understanding that effective site management is a key requisite for achieving key project performance indicators such as time, cost, quality, waste, and safety target, among others. (Mustapha and Naoum, 1998). With increasing project complexity regarding administrative and technicalities, modern day's site management techniques should be able to manipulate all site dynamics towards enhancing project performance. Meanwhile, a key project requirement that is becoming more required of site managers is the extent of project sustainability (Cox et al., 2003; Bassioni et al., 2004), among which waste output is crucial (Udawatta et al., 2015). Currently, the construction industry remains a key target for the global sustainability agenda (Anderson and Thornback, 2002), particularly since the industry consumes the largest portion of materials resources excavated from nature, and generates the greatest portion of landfill waste (Ajayi et al., 2016a). For instance, evidence suggests that the construction industry produces about $44 \%$ of landfill waste in the UK (DEFRA, 2013), 29\% in the US, $44 \%$ in Australia (Shen and Tam, 2002). The figure is similarly alarming in several other countries, with overall global average of about 35\% (CMRA, 2005 in Solís-Guzmán et al., 2009).

The need to reduce the volume of waste generated by the industry has engendered various research and policy formulation. As a result, different construction techniques have been recognised as been essential to reducing construction waste to landfill. For instance, evidence suggests that the use of prefabrication is capable of reducing construction waste by up to 84.7\% (Tam et al., 2007). However, a significant percentage of construction projects do not adopt the use of prefabrication and other offsite construction techniques, thus making it practically impossible to reduce waste through such means. Albeit the importance of site management techniques in driving innovative technologies and engendering project performance (Forster, 2014), most waste management research have concentrated on construction techniques and the use of modern methods of construction (cf. Lu and Yuan, 2010; Poon et al., 2004; Jaillon et al., 2010; Esin and Cosgun, 2007). Whereas the decision to adopt the use of such technologies is usually taken during the design stages, site managers are therefore left without objective weighing of managerial decisions that are capable of reducing waste generated by construction activities. 
As such, the overall aim of this study is to determine the key site management practices for engendering waste minimization in construction projects. The study offers insights that could be used whether a project is adopting offsite construction technique or not, especially as site management is an important aspect of every project (Mustapha and Naoum, 1998). The study fulfils its goal through the following objectives.

1. Evaluation of difference in perception among projects stakeholders concerning critical decisions with impacts on waste generation.

2. Identification of top management practices for minimising on-site construction waste.

3. Exploration of underlying site management measures for waste efficient construction projects.

In order to explore and confirm the site management practices for mitigating construction waste generation, a combination of qualitative and quantitative methods was employed in the study. Based on field studies of construction processes and literature review, some waste efficient site management strategies were identified. These set of measures were then put in a questionnaire survey to explore their generalizability. Descriptive statistics and exploratory factor analysis were used to establish key strategies and underlying measures for mitigating waste through site management practices.

The next section of the paper provides a review of literature. The methodological approach to the study, which includes data sourcing, collection and analytical process are then justified and described. This is followed by the findings, which are presented and discussed before culminating the study with conclusion and implication for practices. This study would assist site managers and other construction experts to understand key management decisions that are requisite to reducing waste generated by construction activities. Implementation of the identified measures could help in diverting substantial proportion of construction waste from landfill.

\section{Site Management and Construction Project Performance}

Effective management of construction site activities is indispensable to overall performance of construction projects (Forster, 2014). It involves direction and supervision of operations on construction projects to ensure timely, safety, quality and cost-effectiveness of the projects, among other success indicators (Harlow, 1992). Usually, a site manager is responsible for the 
whole project, and sometimes in charge of a particular section of the project, thereby reporting to a senior site manager. In either way, the role or decisions taken by the site manager is essential to project success (Fellows et al., 2002). These sets of roles, among others, may include job schedule planning, HR management, discussion with other stakeholders, quality check and control, legal compliance and progress monitoring (Mäki and Kerosuo, 2015).

Although it is clear that the site managers cannot achieve anything in isolation, various relationships have been established between indices of project performance and site management. Site management has a crucial role to play in reducing accident and death on construction projects, especially as the control of site activities and accident-inducing factors are within the role of site management (Golob, 1992). A study to investigate key causes of poor construction further corroborates the assertion that site management is essential to reducing poor safety performance of construction projects (Tam et al., 2004). The study confirmed that poor safety awareness of site managers and inadequate safety training are the main causes of poor safety performance of Chinese construction industry. This further demonstrates the key role of site management in ensuring project success.

As much as project delay has bedevilled the construction industry, evidence suggests that effective site management is a key measure for tackling the problem. According to Faridi and El-Sayegh (2006), poor supervision and poor site management are the leading causes of construction project delay in the UAE. This finding corroborates earlier findings by Kumaraswamy and Chan (1998) who found out that Poor site management and supervision is one of the main causes of construction delay in Hong Kong. Studies across other nations have similarly indicated a strong link between site management practices and project delay (cf. Toor and Ogunlana, 2008; Kaming et al., 1997; Assaf and Heiji, 2006).

The relationship between site management practices and cost effectiveness of projects has also been a subject of an extensive range of literature. A study carried out to investigate the key causes of time and cost overrun in Vietnam suggests that site management functions such as planning and scheduling, and site management experience are key determinants of cost performance of projects (Long et al., 2004). Based on labour intensive nature of the construction industry, the extent to which workers are adequately managed in site 
management roles is important to achieving key project goals such as quality, time and health and safety (Fellows et al., 2002). Thus, with site management being important to achieving various project goals and performance indicators, it is important that site managers and other project stakeholders understand the underlying site management practices for engendering waste minimization in construction projects.

\section{Research Methods}

This study is part of a larger applied research that seeks to develop a holistic protocol for minimising waste generated by construction activities. Based on the aim of this study, which is to identify the key site management practices and measures for mitigating construction waste, qualitative and quantitative research methods were adopted as methods of enquiry. At the early stage of the research, field studies were carried out on six construction sites to explore management measures for reducing waste outputs. This was then followed by a literature review and subsequent operationalization of existing management practices for mitigating construction waste. This approach was selected due to availability of potential waste mitigating site management measures in various waste management studies that are not specifically addressing site management practices. This section justifies and discusses the methodological approach to the study. Figure 1 depicts the methodological flow chart for the study.

\section{1. $\quad$ Field study}

In order to observe the site management practices that are capable of minimising waste generated by construction activities, a total of six construction sites were studied over a period of 30 months. These included one school building, two residential developments, one office block, one health and social care building and one shopping mall. Waste mitigating management practices were observed and documented over the period, and clarification of intent was also made by engaging the project team over the period of field study. The identified sets of waste management practices are presented in Table 1. 


\subsection{Review of Site Management Approaches to Waste Mitigation}

To achieve comprehensive understanding of the existing waste efficient site management practices, literature retrieval process was carried out on two major citation-indexing platforms, which are Engineering Village and Web of Knowledge (Wu et al., 2014). The databases included in the search were Compendex, GEOBASE, Web of Science, BIOSIS, MEDLINE and SciELO without any restriction for the year of publication. Also, SC Imago was used to identify top "waste management and disposal" journals in order to carry out a search on their database. "Waste Management" and "Resources, Conservation and Recycling" were selected after a quick evaluation of scopes of the first ten journals on the list. Based on recommendation in a study by Lu and Yuan (2011), a third journal with wide publications on Construction and Demolition Waste Management, "Waste Management and Research" was also searched for relevant studies. To corroborate the identified papers, relevant publication by the UK government-funded Waste and Resource Action Plan (WRAP) was included. Keywords used for searching the databases and journal repositories include waste efficient, waste management, strategies, reuse, recycling, waste minimization, waste prevention, design and waste, procurement and waste, construction waste, causes of waste, design quality, and design documentation, among others.

Papers that are based on domestic waste, radioactive waste and other types of waste than construction waste were excluded in the search result. Also, papers that discuss nonphysical/non-materials waste were not included in the study. To ensure robustness of the review process, the reference list of the identified papers were manually scanned to check for relevant papers, which may not have been found in the initial search. Albeit the understanding that the identified literature are not aiming at tackling waste from site management perspectives, some of them suggest site management measures with potential for waste minimization. Through a review of the identified literature, some site management practices for engendering project waste minimization are identified as presented in Table 1. 
Table 1: Measures for successful on-site waste management

\begin{tabular}{|c|c|c|c|c|c|c|c|c|}
\hline \multirow[t]{2}{*}{ No. } & \multirow[t]{2}{*}{ On-site Measures } & \multicolumn{6}{|c|}{ Observations } & \multirow[t]{2}{*}{ Sources in literatures } \\
\hline & & 1 & 2 & 3 & 4 & 5 & 6 & \\
\hline M1. & $\begin{array}{l}\text { Detect the construction activities that can admit reusable } \\
\text { materials from the construction }\end{array}$ & $\checkmark$ & & $\checkmark$ & & $\checkmark$ & $\checkmark$ & Del Río Merino et al. (2009). \\
\hline M2. & Waste target set for sub-trades & $\checkmark$ & $\checkmark$ & & $\checkmark$ & $\checkmark$ & & Marinelli et al. (2014) \\
\hline M3. & Recycling target to be set for every project & & & & & & & Oyedele et al. (2013) \\
\hline M4. & Use of safe materials storage facilities & $\checkmark$ & $\checkmark$ & $\checkmark$ & $\checkmark$ & $\checkmark$ & $\checkmark$ & $\begin{array}{l}\text { Dainty and Brooke (2004); } \\
\text { Ekanayake and Ofori (2004) }\end{array}$ \\
\hline M5. & Prevention of over ordering & & $\checkmark$ & & $\checkmark$ & & $\checkmark$ & Begum et al., 2007 \\
\hline M6. & $\begin{array}{l}\text { Prevention of double handling of materials/ Logistic } \\
\text { management to prevent double handling }\end{array}$ & $\checkmark$ & & $\checkmark$ & & $\checkmark$ & & $\begin{array}{l}\text { Al-Hajj and Hamani (2011); Cha et } \\
\text { al. (2009) }\end{array}$ \\
\hline M7. & Use of reclaimed materials & & $\checkmark$ & & & & $\checkmark$ & Domingo et al. (2009) \\
\hline M8. & Construction with standard materials & & & & & & & Cha et al. (2009) \\
\hline M9. & On-site materials compactors & & & & & & & Dainty and Brooke (2004) \\
\hline M10. & Reuse of off-cuts materials (such as wood) & $\checkmark$ & $\checkmark$ & $\checkmark$ & $\checkmark$ & $\checkmark$ & $\checkmark$ & Al-Hajj and Hamani (2011) \\
\hline M11. & Use of demolition and excavation materials for landscape & & & $\checkmark$ & & $\checkmark$ & & WRAP (2009) \\
\hline M12. & $\begin{array}{l}\text { Prefabrication space in the work site for correct } \\
\text { management of C\&D waste }\end{array}$ & & $\checkmark$ & & $\checkmark$ & & $\checkmark$ & Lu and Yuan (2013) \\
\hline M13. & Follow the project drawings/designs & $\checkmark$ & $\checkmark$ & $\checkmark$ & $\checkmark$ & $\checkmark$ & $\checkmark$ & $\begin{array}{l}\text { Lu and Yuan (2010); Saez et al. } \\
\text { (2013) }\end{array}$ \\
\hline M14. & Periodic checks on the use of C\&D waste containers & $\checkmark$ & $\checkmark$ & $\checkmark$ & $\checkmark$ & $\checkmark$ & $\checkmark$ & Saez et al. (2013) \\
\hline M15. & Preventing waste mixture with soil & & & $\checkmark$ & & $\checkmark$ & & Jingkuang and Yousong (2011) \\
\hline M16. & Providing bins for collecting wastes for each sub-contractor & $\checkmark$ & $\checkmark$ & $\checkmark$ & $\checkmark$ & $\checkmark$ & $\checkmark$ & Cha et al. (2009) \\
\hline M17. & Dedicated space for sorting of waste & $\checkmark$ & & & $\checkmark$ & $\checkmark$ & & $\begin{array}{l}\text { Wang et al.(2014); Lu and Yuan } \\
\text { (2010) }\end{array}$ \\
\hline M18. & Ensure fewer design changes during construction & & $\checkmark$ & $\checkmark$ & & $\checkmark$ & & Al-Hajj and Iskandarani (2011) \\
\hline M19. & Setting up temporary bins at each building zone & & $\checkmark$ & & & & $\checkmark$ & Jingkuang and Yousong (2011) \\
\hline M20. & Adequate site access for materials delivery and movement & & & & & & & Negapan, et al. (2013) \\
\hline M21. & $\begin{array}{l}\text { Waste auditing to monitor and record environmental } \\
\text { performance on-site }\end{array}$ & & & & & & & Dainty and Brooke (2004) \\
\hline M22. & Central areas for cutting and storage & & & & & & & Tam $(2008)$ \\
\hline M23. & $\begin{array}{l}\text { Provision of waste skips for specific materials (waste } \\
\text { segregation) }\end{array}$ & $\checkmark$ & & & & $\checkmark$ & $\checkmark$ & $\begin{array}{l}\text { Al-Hajj and Hamani (2011); } \\
\text { Marinelli et al. (2014); Del Río } \\
\text { Merino et al. (2010) }\end{array}$ \\
\hline M24. & $\begin{array}{l}\text { Reuse material scraps from cutting stock-length material } \\
\text { into shorter pieces }\end{array}$ & & $\checkmark$ & $\checkmark$ & $\checkmark$ & & & Faniran and Caban (1998) \\
\hline M25. & Soil remains to be used on the same site & $\checkmark$ & $\checkmark$ & $\checkmark$ & $\checkmark$ & $\checkmark$ & $\checkmark$ & Begum et al. (2009) \\
\hline M26. & Sorting and reuse/recycling of waste & & $\checkmark$ & & $\checkmark$ & $\checkmark$ & & $\begin{array}{l}\text { Hassan et al. (2012); Yeheyis et al. } \\
\text { (2013) }\end{array}$ \\
\hline M27. & Making sub-contractors responsible for waste disposal & $\checkmark$ & $\checkmark$ & $\checkmark$ & $\checkmark$ & $\checkmark$ & $\checkmark$ & Domingo et al. (2009) \\
\hline M28. & Maximisation of on-site reuse of materials & & & $\checkmark$ & $\checkmark$ & & & Marinelli et al. (2014) Yuan (2013) \\
\hline
\end{tabular}




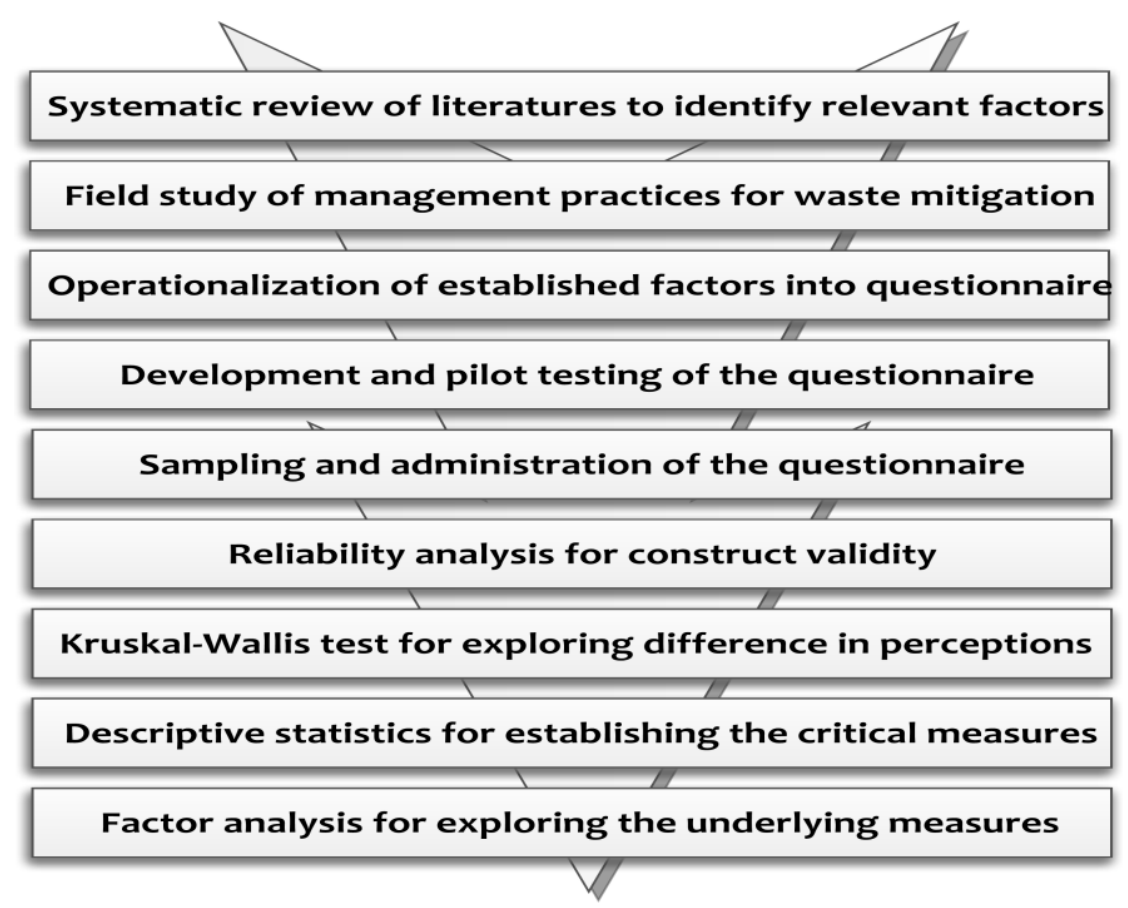

Figure 1: Methodological flow chart for the study

\subsection{Questionnaire Survey}

In addition to respondents' information, the identified sets of measures are operationalised into questionnaire survey in line with positivism epistemological stance. This approach provides the opportunity of cheaply reaching out to large audience, through a standardised means of data collection, thereby aiding generalizability of the research findings (Creswell, 2013). Potential threat to questionnaire survey, regarding content validity, was addressed through a comprehensive literature review, while construct and face validity was ensured through a pilot study. Seven respondents, including two site waste managers, two construction project managers, one project architect and two site engineers, were involved in the pilot studies. The pilot study provided additional opportunity of asking the respondents about other site management practices that could reduce construction waste generation. The feedback from the pilot studies was used to improve the questionnaire. The improved questionnaire, which served as means of data collection, consists of 28 factors on a Likert scale of 1 to 5, where 5 represents "most important" and 1 represents "not important".

Using directories of five UK professional bodies and list of the top 100 construction companies as sampling frame, 200 questionnaires were sent to randomly selected respondents through email and postal services. The five professional bodies included Association of 
Project Managers (APM), Chartered Institute of Buildings (CIOB), Chartered Institute of Waste Managers (CIWM), Chartered Institute of Architectural Technologists (CIAT) and Royal Institute of Chartered Surveyors (RICS). After series of email reminders, 131 responses were received, representing a response rate of $65.5 \%$. This is within a good response rate according to Fincham (2008). Out of these, three questionnaires were incomplete and were removed from further analysis. Table 2 shows the distribution of 128 responses that were used for data analysis.

Table 2: Distribution of the research respondents

\begin{tabular}{|c|c|c|}
\hline & Sample size & \% of Respondents \\
\hline \multicolumn{3}{|l|}{ Types of Organisation } \\
\hline Design Firms (Architecture and Engineering) & 21 & 16.4 \\
\hline Contractor & 54 & 42.2 \\
\hline Project management & 20 & 15.6 \\
\hline Waste management & 33 & 25.8 \\
\hline \multicolumn{3}{|l|}{ Profession/Job roles } \\
\hline Site Architect & 17 & 13.3 \\
\hline Site Engineer (Civil/Structure) & 29 & 22.6 \\
\hline Project Managers & 49 & 28.3 \\
\hline Site waste managers & 33 & 25.8 \\
\hline \multicolumn{3}{|l|}{ Years of Experience } \\
\hline $0-5$ & 4 & 3.1 \\
\hline $6-10$ & 25 & 19.5 \\
\hline $11-15$ & 33 & 25.7 \\
\hline $16-20$ & 26 & 20.3 \\
\hline $21-25$ & 31 & 24.2 \\
\hline 26 and Above & 9 & 7.0 \\
\hline
\end{tabular}

\section{Data Analysis and Findings}

In this study, quantitative data analysis was carried out through some statistical analyses, which are justified and discussed in this section.

\subsection{Reliability Analysis}

Internal consistency of criteria contained in the questionnaire, as well as the suitability of the data for analysis, was evaluated using Cronbach's Alpha. This is in line with the recommendation that it is important that Cronbach's alpha coefficient be determined, especially when using Likert scale on a questionnaire (Field, 2009; Nunnally and Bernstein, 
2007). With Cronbach's alpha ranging from 0 to 1 , a value of 0.7 represents an acceptable consistency, while 0.8 indicates a good internal consistency according to Nunnally and Bernstein (2007). Using SPSS version 22, the Cronbach's alpha coefficient for this study is 0.944. This confirms excellent reliability and internal consistency of the items on the research instrument. In order to confirm whether all items on the questionnaire are contributing to the good internal consistency, "Cronbach's alpha if item deleted" were evaluated as suggested by Field (2009). In this case, any item with Cronbach's alpha above the established value of 0.944 means that such item is not a good construct and should be deleted from the list of variables. As shown in Table 3, only one variable $(\mathrm{M}-8$ : construction with standard materials) have its value above 0.944 and it is therefore removed from further analysis. On deleting the outlier, the Cronbach's alpha coefficient improved to 0.949.

\subsection{Kruskal-Wallis Test}

Kruskal-Wallis test is a non-parametric test of null hypothesis that is employed in statistics to evaluate whether different categories of respondents differ about a particular hypothesis (Gupta, 1999). In this study, it is employed to assess whether organisation types affect respondents' perception of key site management practices for waste minimization. As such, it has been used to determine whether responses differ among those working for design firms, contractors, project management companies and site waste management company. According to Field (2009), a p-value below 0.05 in Kruskal-Wallis test indicates that there is a significant difference between the groups of participant about the affected variable at $95 \%$ confidence level. Any p-value above 0.05 indicates that there is no significant difference among the groups. As shown in Table 3, the p-value (sig.) shows that there is no difference of perception among the groups about all but one variable, which is " $\mathrm{M}-7$ : use of reclaimed material".

\subsection{Descriptive Mean Testing}

Descriptive mean testing is a measure of central tendency, usually employed by statisticians when there is need to determine the means and relative significance of a set of statistical variables (Field, 2009). The purpose of descriptive analysis in this study was to determine the key site management practices that are capable of engendering construction waste minimization. In this case, a higher means value indicates significance of the management measure. This is based on the importance index of the Likert scale that ranges from 1-5, 
where 1 represents not important, and 5 represents most important. Table 3 shows the means as well as the level of significance of each site management measure. As shown in the table, the top four site management practices for engendering waste minimization are:

1. M13 - ensure that project drawings/design is adequately followed.

2. M23 - provision of waste skips for specific materials.

3. M28 - maximisation of on-site reuse of materials.

4. M18 - ensure fewer design changes during construction

Summarily, these sets of measures suggest that decisions concerning design/contract management and materials reuse are the key measures for engendering construction waste minimization.

\subsection{Exploratory Factor Analysis}

Based on the aim of this study, which is to suggest site management measures for engendering construction waste minimization, it is important that key underlying measures be established from the established sets of identified factor. In order to achieve this, factor analysis was carried out for the purpose of substituting the 27 factors with a small number of practices that are capable of providing waste mitigating effects as the whole list of measures. Usually, factor analysis is carried out through three steps, which are a test for suitability of data, factor extraction and factor rotation (Field, 2009).

As a means of testing the suitability of the data for factor analysis, Kaiser-Meyer-Olkin (KMO), Bartlett's test of sphericity and determinant of coefficient matrix tests were carried out. A set of data is deemed suitable for factor analysis if it has KMO value of sampling adequacy above 0.5 , Bartlett's test value below 0.05 and coefficient matrix above 0.00001 (Field, 2009; Tabachnick and Fidell, 2001). Using SPSS version 22, this study shows a KMO value of 0.62 , which is higher than the minimum acceptable value. The Bartlett's test shows a value of $8.1414 \mathrm{E}-34$, which is less than the maximum value of 0.05 . The coefficient matrix also indicated a value of 5.36E-4, confirming the suitability of the data for factor analysis.

In order to determine the number of key factors that will suitably represent the whole factor, Principal Component Analysis (PCA) was used for factor extraction. Under the analysis, 
minimum Eigenvalue of 1 was retained (Nunnally and Bernstein, 2007), and diagonal of the anti-imaging matrix was examined to exclude factor having a diagonal matrix value below 0.5 as recommended by Field (2009). This led to a deletion of two factors, which are $\mathrm{M}-12$ : prefabrication space in the work site for correct management of C\&D waste, and M-26: sorting and reuse/recycling of waste. In all, four components were extracted from the PCA. The orthogonal factor rotation was carried out using Varimax method. This retained the four components but with more redistribution of the components, Eigen value and percentage variance for each component. Out of the remaining factors, three factors loaded significantly in two components, and they were subsequently dropped as suggested by Tabachnick and Fidell (2001). The three factors are M9-on-site materials compactors, M14-periodic checks on the use of C\&D waste containers and M21-waste auditing to monitor and record environmental performance on-site. The result indicated that the four-factor solution accounted for $96.093 \%$ of the total variance as shown in Table 4.

The four groupings were interpreted and labelled based on the underlying factor shared by each group of the components. Taking Eigen value and percentage of variance as the measures of importance for each component, the four components, in order of their importance, are contract management, waste segregation, materials reuse and logistics management. 
Table 3: Outputs of reliability analysis, Kruskal-Wallis test and descriptive statistics

\begin{tabular}{|c|c|c|c|c|c|c|c|}
\hline \multirow[t]{2}{*}{ SN } & \multirow[t]{2}{*}{ Factors } & \multicolumn{2}{|c|}{ Reliability analysis } & \multicolumn{2}{|c|}{ Kruskal-Wallis test } & \multicolumn{2}{|c|}{ Significance Index } \\
\hline & & $\begin{array}{l}\text { Cronbach's } \\
\text { Alpha }^{\mathrm{a}}\end{array}$ & $\begin{array}{l}\text { Cronbach } \alpha \text { if } \\
\text { item deleted }\end{array}$ & $\begin{array}{l}\text { Chi } \\
\text { Square }\end{array}$ & Sig. ${ }^{b}$ & $\begin{array}{l}\text { Mean } \\
\text { Value }\end{array}$ & $\begin{array}{l}\text { Overall } \\
\text { Ranking }\end{array}$ \\
\hline $\mathrm{M}-1$. & Detect the construction activities that can admit reusable materials from the & .625 & .942 & 5.438 & .245 & 3.8261 & 18 \\
\hline $\mathrm{M}-2$. & Waste target set for sub-trades & .813 & .939 & 1.333 & .856 & 3.8261 & 17 \\
\hline $\mathrm{M}-3$. & Recycling target to be set for every project & .777 & .940 & 2.259 & .688 & 4.0435 & 12 \\
\hline $\mathrm{M}-4$. & Use of safe materials storage facilities & .451 & .944 & 3.579 & .466 & 4.0870 & 9 \\
\hline $\mathrm{M}-5$. & Prevention of over ordering & .597 & .942 & 3.877 & .423 & 3.8696 & 15 \\
\hline $\mathrm{M}-6$. & Prevention of double handling of materials/ Logistic management to prevent double & .610 & .942 & 5.303 & .258 & 4.1304 & 7 \\
\hline $\mathrm{M}-7$. & **Use of reclaimed materials** & .444 & .944 & 10.331 & .035 & 4.0435 & 11 \\
\hline $\mathrm{M}-8$ & $* * *$ Construction with standard materials**** & -.062 & .949 & 3.576 & .466 & 4.0000 & 14 \\
\hline $\mathrm{M}-9$. & On-site materials compactors & .691 & .941 & 4.821 & .306 & 3.1739 & 28 \\
\hline $\mathrm{M}-10$. & Reuse of off-cuts materials (such as wood) & .716 & .941 & 4.965 & .291 & 3.6522 & 22 \\
\hline $\mathrm{M}-11$. & Use of demolition and excavation materials for landscape mulch & .632 & .942 & 4.852 & .303 & 4.1739 & 5 \\
\hline $\mathrm{M}-12$. & Prefabrication space in the work site for correct management of $C \& D$ waste & .754 & .941 & 6.309 & .177 & 3.5000 & 26 \\
\hline $\mathrm{M}-13$. & Follow the project drawings/designs & .422 & .944 & 1.585 & .812 & 4.3913 & 1 \\
\hline $\mathrm{M}-14$. & Periodic checks on the use of $C \& D$ waste containers & .868 & .939 & 1.318 & .858 & 3.5652 & 24 \\
\hline $\mathrm{M}-15$. & Preventing waste mixture with soil & .817 & .940 & 1.677 & .795 & 4.0870 & 10 \\
\hline $\mathrm{M}-16$. & Providing bins for collecting wastes for each sub-contractor & .564 & .943 & 1.110 & .893 & 3.3636 & 27 \\
\hline $\mathrm{M}-17$. & Dedicated space for sorting of waste & .721 & .941 & 3.047 & .550 & 3.7727 & 20 \\
\hline $\mathrm{M}-18$. & Ensure fewer design changes during construction & .441 & .944 & 4.838 & .304 & 4.3043 & 4 \\
\hline $\mathrm{M}-19$ & Setting up temporary bins at each building zone & .520 & .943 & .530 & .970 & 3.7727 & 19 \\
\hline$M-20$. & Adequate site access for materials delivery and movement & .396 & .944 & .515 & .972 & 4.0000 & 13 \\
\hline $\mathrm{M}-21$. & Waste auditing to monitor and record environmental performance on-site & .854 & .939 & 8.247 & .083 & 3.8261 & 16 \\
\hline $\mathrm{M}-22$. & Central areas for cutting and storage & .660 & .941 & 5.658 & .226 & 3.5909 & 23 \\
\hline $\mathrm{M}-23$. & Provision of waste skips for specific materials (waste segregation) & .732 & .942 & 2.100 & .717 & 4.3182 & 2 \\
\hline M-24. & Reuse material scraps from cutting stock-length material into shorter pieces & .567 & .942 & 7.382 & .117 & 3.6957 & 21 \\
\hline $\mathrm{M}-25$. & Soil remains to be used on the same site & .632 & .942 & 4.496 & .343 & 4.0870 & 8 \\
\hline $\mathrm{M}-26$. & Sorting and reuse/recycling of waste & .699 & .942 & 3.443 & .487 & 4.1739 & 6 \\
\hline $\mathrm{M}-27$. & Making sub-contractors responsible for waste disposal & .498 & .944 & 4.581 & .333 & 3.5217 & 25 \\
\hline $\mathrm{M}-28$. & Maximisation of on-site reuse of materials & .493 & .943 & 2.569 & .632 & 4.3043 & 3 \\
\hline
\end{tabular}




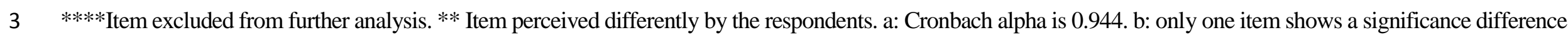

Table 4: Component labelling and its associated criteria

\begin{tabular}{|c|c|c|c|c|c|}
\hline SN & Extracted and Rotated Components & Eigen Value & $\begin{array}{l}\% \text { of } \\
\text { Variance }\end{array}$ & $\begin{array}{l}\text { Factor } \\
\text { Loading }\end{array}$ & $\begin{array}{l}\% \text { Weighting } \\
\text { within group }\end{array}$ \\
\hline COMP -1 & Contract management & 9.474 & 35.174 & & \\
\hline$M-2$ & Waste target set for sub-trades & & & 0.734 & 19.3 \\
\hline$M-3$ & Recycling target to be set for every project & & & 0.538 & 14.2 \\
\hline$M-13$ & Follow the project drawings/designs & & & 0.885 & 23.3 \\
\hline$M-18$ & Ensure fewer design changes during construction & & & 0.898 & 23.7 \\
\hline$M-27$ & Making sub-contractors responsible for waste disposal & & & 0.742 & 19.5 \\
\hline COMP - 2 & Waste Segregation & 8.096 & 29.985 & & \\
\hline$M-15$ & Preventing waste mixture with soil & & & 0.729 & 19.6 \\
\hline$M-16$ & Providing bins for collecting wastes for each sub-contractor & & & 0.564 & 15.2 \\
\hline$M-17$ & Dedicated space for sorting of waste & & & 0.777 & 20.9 \\
\hline$M-19$ & Setting up temporary bins for each building zone & & & 0.812 & 21.8 \\
\hline$M-23$ & Provision of waste skips for specific materials (waste segregation) & & & 0.837 & 22.5 \\
\hline COMP -3 & Materials reuse & 4.975 & 18.427 & & \\
\hline $\mathrm{M}-1$ & Detect the construction activities that can admit reusable materials from the & & & 0.582 & 13.3 \\
\hline $\mathrm{M}-7$ & Use of reclaimed materials & & & 0.778 & 17.8 \\
\hline $\mathrm{M}-10$ & Reuse of off-cuts materials (such as wood) & & & 0.661 & 15.1 \\
\hline $\mathrm{M}-11$ & Use of demolition and excavation materials for landscape & & & 0.748 & 17.0 \\
\hline $\mathrm{M}-25$ & Soil remains to be used on the same site & & & 0.701 & 16.0 \\
\hline $\mathrm{M}-28$ & Maximisation of on-site reuse of materials & & & 0.910 & 20.8 \\
\hline COMP -4 & Materials Logistic Management & 3.377 & 12.507 & & \\
\hline $\mathrm{M}-4$ & Use of safe materials storage facilities & & & 0.662 & 17.6 \\
\hline$M-5$ & Prevention of over ordering & & & 0.651 & 17.4 \\
\hline$M-6$ & Prevention of double handling of materials/ Logistic management to prevent double & & & 0.783 & 20.9 \\
\hline $\mathrm{M}-20$ & Adequate site access for materials delivery and movement & & & 0.920 & 24.5 \\
\hline $\mathrm{M}-22$ & Central areas for cutting and storage & & & 0.736 & 19.6 \\
\hline
\end{tabular}




\section{Discussion}

Findings from Kruskal-Wallis test, descriptive statistics and exploratory factor analysis are discussed in this section.

\subsection{Statistical Difference between the Perceptions of the Respondents}

The only factor on which the respondents differ is the "use of reclaimed material" as a key measure to reduce construction waste. A further probe into the mean ranking indicates that employees of waste management companies strongly posit that the use of reclaimed materials is a key requisite to reducing waste, while other groups of respondents rate the measure as being moderately important. This disparity portrays the level at which each group of participants perceive waste. While site waste managers perceive construction waste at a holistic level of diversion from landfill, other project teams perceive waste at project level. Although the use of secondary products is key to reducing waste landfilling (Oyedele et al., 2014), it does not necessarily contribute to an ongoing project waste reduction. As such, the designers and contractors do not view the use of recycled product as a means of reducing construction waste. Nonetheless, there is a need for project team to adopt the use of secondary products in order to reduce waste intensiveness of the construction industry at holistic level (Ajayi et al., 2015).

\subsection{Top Waste Efficient Site Management Practices}

As a means of further expatiating the top rated site management measures for engendering construction waste minimization, this section discusses four key waste efficient practices as ranked in Table 3.

\subsubsection{Adherence to project drawings/design}

The result shows that the most important site management activity for construction waste minimization is adherence to design document, thereby preventing error and variation from the document. This finding suggests that monitoring of design compliance, and ensuring that building operatives work in accordance with design document is a key role of site management team. Due to this, contemporary site management role requires adequate knowledge of design interpretation, just as designers require knowledge of construction 
operation and sequence to design out waste (Ajayi et al., 2016b). Nonetheless, Dainty and Brooke (2004) suggests that most error at construction stage is usually due to contractors' poor knowledge of the design and its documentation. This results in insufficient understanding of design, which ultimately results in error and reworks. Due to this, contemporary site management role requires adequate knowledge of design interpretation, in order to prevent errors that could lead to reworks and waste.

This study buttresses earlier finding, which suggests that the key causes of waste in construction project is deviation from design document and its associated rework (Formoso et al., 2002). Once there is unintended deviation from adequately prepared design document, there is need for demolishing such aspect of construction before reworks could take place. This generates huge proportion of waste, while also affecting cost and duration of construction projects (Love and Li, 2000). According to Hwang et al. (2012), rework as caused by design errors or poor adherence to project drawing could increase project cost by $5 \%$ or more. Thus, in a bid to reduce waste generated by construction activities, there is need for site management team to adequately understand the design document, and ensure that construction activities are guided by the design documents.

\subsubsection{Waste skips for specific materials}

Construction waste segregation is an important site management practice for reducing waste landfilled by construction activities. The respondent agreed that to reduce total waste generated, there is need for effective separation of waste, by providing waste skips for specific materials. Although waste segregation in itself is not a strategy for waste reduction, it is a requisite for facilitating materials reuse and recycling. As a strategy adoptable after waste has occurred, recycling requires sorting of generated waste into "recyclable and nonrecyclables" during the construction activities or at the recycling site (Barros et al., 1998). The option of site sorting has been widely encouraged across the UK, as it eases recycling operations and ensures accurate separation of inert and non-inert materials (Poon et al., 2001). With these practices, there is likelihood of on-site reuse of the materials in waste skips or for other projects (Tam, 2008). This will equally help in preventing waste mixture with soil (Jingkuang and Yousong, 2011). As such, waste segregation provides both short and long-term benefits of on-site materials reuse and ease of waste recycling. 


\subsubsection{Maximisation of materials reuse}

Another major site management practice that is capable of reducing construction waste landfilling is the maximisation of on-site materials reuse. This practice is ranked third out of the 28 identified measures for engendering waste minimization. Based on the importance of this practice, previous studies and policy documents have identified measures through which materials reuse could be maximised on construction project sites. For instance, a study by Li and Wong (2003) suggests that incentivising waste minimization practices is a means of enhancing materials reuse and waste prevention. This was also buttressed by Chen et al. (2002) who posit that materials reuse and subsequent waste reduction could be achieved by educating workers and providing adequate incentives for their waste minimization efforts. According to Marinelli et al. (2014), material reuse could be maximised on-site by setting waste targets for sub-trades, or by setting waste minimization as part of project goals. Similarly, there is need for effective coordination of project participants and communication of the need for waste minimization.

Begum (2009) recommended that by reusing soil remains on site, substantial proportion of waste could be diverted from landfill. In line with this, WRAP (2009) identified that apart from using demolition and excavation materials for filling, it could as well be used for landscape mulch. In either way, maximisation of on-site materials reuse has several environmental benefits. Apart from reducing pressure on landfill sites, it prevents the need to transport the materials or reprocessing it through recycling, which in itself requires some amount of energy (Ajayi et al., 2014).

\subsubsection{Fewer design changes}

Like design errors and poor adherence to design instruction, design change is a major cause of reworks and subsequent waste generation in construction projects (Osmani et al., 2008). This is further exacerbated when such change is not adequately communicated to the project team (Faniran and Caban, 1998). In line with the causative influence of design change and its poor communication on construction waste generation, a major decision for engendering waste minimization is to reduce the number and extent of design change during construction process. This finding corroborates earlier studies, which suggest that design freeze is requisite to reducing waste generated by construction activities (Osmani et al., 2008; Oyedele et al., 
2013). Where design change is inevitable, it is important that project resources and activities be properly rescheduled, while such change should be properly communicated to all project stakeholders.

\subsection{Underlying Site Management Practices for Waste Mitigation}

Based on the four-factor components extracted from factor analysis, this section discusses the underlying measures for engendering construction waste minimization. Figure 2 depicts the four components of waste effective site management practice.

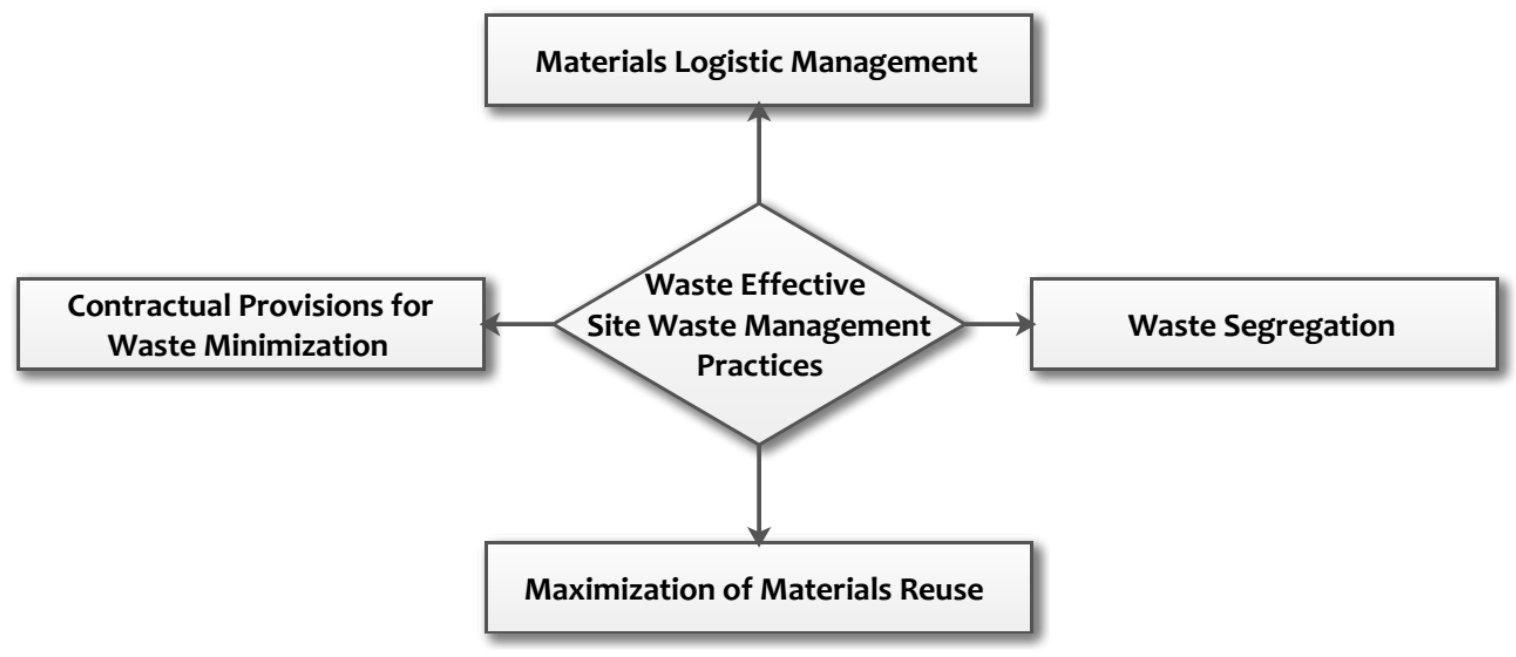

Figure 2: Underlying measures for reducing waste through site management practices

\subsubsection{Contract Management for Waste Minimization}

This factor grouping has the highest percentage of the total variance (35.174\%), and it consists of four policy suggestions as shown in Table 4. The factor name, "contract management for waste minimization", was imposed on the factor grouping, as all measures that made up the group are suggesting measures that could only be achieved through contractual clauses. For instance, a key factor that contributes to the component is a fewer design change, while another factor requires that sub-contractor should be made responsible for their waste disposal. These measures could be achieved through contractual clauses that consider waste minimization as part of key success factors.

Usually, construction waste minimisation receives little or no attention in several projects (Ajayi et al., 2015), due to lack of its consideration in project contracts (Osmani, 2013). 
Time, cost and quality, among others, have become the top performance indicators for benchmarking success of construction projects (Sanvido et al., 1992). Because of this, site managers and other project stakeholders always give their priority to activities that could directly contribute to indices upon which their performance would be measured. This is rational from static point of view, as waste minimization is not usually required of project stakeholders from benchmarking point of view. Nonetheless, this practice is albeit the understanding that waste minimization has tendency of improving cost of construction projects (BRE, 2003). Also, the use of project contracts to prevent some of the key causes of construction waste could significantly prevent cost and time overrun, which are rife in the construction industry (Assaf and Al-Hejji, 2006). As deviation from project drawings and incessant design changes usually result in reworks and subsequent waste generation, a contractual clause that freezes design is a requisite for reducing waste intensiveness of the construction industry (Oyedele et al., 2013; Ekanayake and Ofori, 2004). A project that sets waste and recycling target as part of contractual provision is more likely to divert substantial waste from landfill site (Marinelli et al., 2014). Thus, this factor advocates the need for using contractual clauses as underlying requisites for engendering waste minimization on construction sites.

\subsubsection{Waste Segregation}

Waste segregation is another measure for engendering waste minimization on construction sites. The factor component consists of five factors, all of which suggest measures for ensuring effective waste collection and segregation on-site, and it has a total variance of 29.985\%. This suggests that construction waste could not be minimised without proper collection and segregation of different waste types on site. The key measures that contribute to the factor suggest provision of waste skips for different materials and setting up of waste bins at each building zone, in case of large construction projects. In order to ensure effectiveness of waste segregation, it is important that recyclable waste is separated from non-recyclable waste (Cha et al., 2009), while inert and non-inert waste are also separated for proper treatment. Similarly, spaces for waste sorting, adequate positioning of waste skips and its proper labelling are important for effective waste collection, segregation, reuse and recycling. This further reinforces the importance of waste segregation as a requisite for effective waste treatment as well as the likelihood of materials reuse and recycling activities. 


\subsubsection{Materials Reuse}

The third factor category has a total variance of $18.427 \%$, and it is labelled as "material reuse" due to its integration of six component factors that requires reuse of construction materials. It requires maximisation of on-site reuse of materials, and it specifically requires reuse of such materials as off-cut, soil remains, as well as excavation and demolition materials. This factor incorporates various waste mitigating practices suggested by previous studies (Cf. Del Río Merino et al., 2009; Al-Hajj and Hamani, 2011; Cha et al., 2009; Lu and Yuan, 2010). As such, it is a key measure that combines various strategies that are capable of diverting substantial proportion of construction waste from landfill. Apart from preventing landfilling, materials reuse, in this case, prevents the need for waste transportation and recycling, which is not without its negative environmental impacts (Ajayi et al., 2014). In addition to reuse of materials on-site, this factor requires the use of reclaimed materials for construction activities. This could be achieved by identifying the construction activities that could admit secondary materials, rather than using virgin materials that require substantial amount of energy. Specification and subsequent use of reclaim materials would as such prevent landfilling of waste generated from other sites (Oyedele et al., 2013), thereby reducing waste intensiveness of the construction industry.

\subsubsection{Logistics Management}

The fourth component of the underlying site management strategies for waste minimization is labelled as site logistic management. The factor component integrates five measures for preventing waste generation, and it has a total variance of $12.507 \%$. It is an essential factor that entails effective planning of materials ordering and purchase, inbound and on-site materials movement, and materials warehousing. The factor component suggests that waste minimization requires adequate estimation of materials required at different stages of the projects in a bid to reduce the potential for materials over ordering and subsequent leftover, which is a key cause of waste generation (Begum et al., 2007). Asides ordering of appropriate materials, inadequate site access for materials delivery and its on-site movement could result in materials breakage and subsequent waste generation (Dainty and Brooke, 2004). It is, therefore, imperative that site management functions include an effective planning of materials purchase, delivery, storage and handling. These would prevent waste due to breakages, damages due to human error, poor handling, and weather, among others. 


\section{Conclusion}

Effective site management is increasingly recognised as the strategic approach for achieving the required performance in construction projects. This is because of understanding that project performance could only be achieved through an effective site management practices. Based on this relevance of site management to achievement of project goals, this study explores critical management practices that are capable of influencing on-site waste minimization. This is especially required, as the industry contributes the largest proportion of waste to landfill. After a review of literature and field studies, the study employed descriptive statistics and exploratory factor analysis to determine the key and underlying site management measures for reducing waste intensiveness of the industry.

The study suggests that site management functions could significantly reduce waste generation by ensuring that project drawing is strictly adhered to, and by ensuring fewer or no design changes. In a bid to ensure this, contemporary site management role requires adequate knowledge of design interpretation, just as designers require knowledge of construction operation and sequence in order to design out waste. This is especially required, as contractors' poor knowledge of design documentation and interpretation would increase construction waste generation. A site manager should as such be equipped with the knowledge to prevent design variation, which would otherwise result in reworks and subsequent waste generation.

The study similarly implies that effective segregation of waste, through provision of waste skips for specific materials, is essential to mitigating overall waste disposed from a construction site. In addition to being a key success factors for a waste-efficient project, the result of the factor analysis suggests that waste segregation is an underlying measure for achieving other waste minimization practices. For instance, on-site materials reuse could be largely influenced by how well the different waste categories are properly segregated. This would also ensure that the waste skips are well located for ease of considering the materials for reuse, while also ensuring that reusable materials are not mixed with soil. Thus, by adequately segregating the waste, there is tendency of reusing some materials from the waste skips. 
Apart from waste segregation and maximisation of its on-site reuse which doubles as key and underlying site management measures for engendering waste minimization, this study suggests the need for project contracts to support waste mitigation. With a total variance of over $35 \%$, contractual clauses are requisites for waste effectiveness of construction projects. The result shows that without contractual provisions that consider waste minimization as part of key success factors or that seeks to tackle key waste causative factors, no substantial progress could be made about waste minimization. This is due to the understanding that site managers and other project stakeholders always give their priority to activities that could directly contribute to indices upon which their performance would be measured. Without including waste minimization in contract documents, contractors would only address waste if it makes economic sense to them, especially as their performance would not be judged by the volume of waste diverted from landfill.

Also, logistics management, which encompasses materials ordering and purchase, inbound and on-site materials movement, and materials warehousing, should be given utmost attention in site management. This could be achieved by ensuring using Just in Time materials delivery system, which is capable of preventing over ordering and stockpiling of materials. Effective logistic management also entails measures for preventing double handling, which could be achieved by centrally locating the materials storage facilities and by delivering the materials as at when needed. By addressing the identified sets of key and underlying measures identified in this study, substantial proportion of construction waste could be reduced.

This study has been carried out with the goal of establishing the management practices for mitigating waste generated by construction activities. It has explored the measures within job roles of construction site managers, and the key and underlying management approach for tackling waste generation have been discussed. Although the use of modern methods of construction has been found to be capable of reducing construction waste, the decision to use such techniques as prefabrication and modular construction could have been made before the appointment of a construction site managers. This study provided soft measures that could be applied in construction site management practices, irrespective of the construction techniques. As the study was carried out within the UK context, further studies could evaluate generalizability of the findings to other regions. 


\section{Acknowledgement}

The authors would like to express their sincere gratitude to Innovate UK (formerly Technology Strategy Board - TSB) and Balfour Beatty PLC for providing financial support for the research (under "Rethinking the build process"), through application No: 22883158278 and file reference No: 101346.

\section{References}

Ajayi, S.O., Oyedele, L.O., Bilal, M., Akinade, O.O., Alaka, H.A., Owolabi, H.A. \& Kadiri, K.O., 2015. Waste effectiveness of the construction industry: Understanding the impediments and requisites for improvements. Resources, Conservation and Recycling, 102, pp.101-112.

Ajayi, S.O., Oyedele, L.O., Akinade, O.O., Bilal, M., Owolabi, H.A., Alaka, H.A. and Kadiri, K.O., 2016. Reducing waste to landfill: A need for cultural change in the UK construction industry. Journal of Building Engineering, 5, pp.185-193.

Ajayi, S.O., Oyedele, L.O., Kadiri, K.O., Akinade, O.O., Bilal, M., Owolabi, H.A. \& Alaka, H.A., (2016b). Competency -Based Measures for Designing out Construction Waste: Task and Contextual Attributes. Engineering, Construction and Architectural Management, 24(3), DOI: 10.1108/ECAM-06-2015-0095.

Akinade, O.O., Oyedele, L.O., Bilal, M., Ajayi, S.O., Owolabi, H.A., Alaka, H.A. \& Bello, S.A., 2015. Waste minimisation through deconstruction: A BIM based Deconstructability Assessment Score (BIM-DAS). Resources, Conservation and Recycling, 105, pp.167-176.

Al-Hajj, A., \& Iskandarani, T. 2012. Reducing Waste Generation on the UAE Construction Sites. Paper presented at 7th International Conference on Innovation in Architecture, Engineering and Construction, São Paulo, Brazil.

Assaf, S. A., \& Al-Hejji, S. 2006. Causes of delay in large construction projects. International Journal of Project Management, 24(4), 349-357.

Assaf, S.A. \& Al-Hejji, S., 2006. Causes of delay in large construction projects. International journal of project management, 24(4), pp.349-357.

Barros, A.I., Dekker, R., \& Scholten, V. 1998. A two-level network for recycling sand: A case study. European Journal of Operational Research, 110(2), pp. 199-214 
Bassioni, H.A., Price, A.D. \& Hassan, T.M., 2004. Performance measurement in construction. Journal of management in engineering, 20(2), pp.42-50.

Begum, R. A., Siwar, C., Pereira, J. J., \& Jaafar, A. H. 2007. Implementation of waste management and minimisation in the construction industry of Malaysia. Resources, Conservation and Recycling, 51(1), pp. 190-202.

Bilal, M., Oyedele, L.O., Qadir, J., Munir, K., Akinade, O.O., Ajayi, S.O., Alaka, H.A. and Owolabi, H.A., 2015. Analysis of critical features and evaluation of BIM software: towards a plug-in for construction waste minimization using big data. International Journal of Sustainable Building Technology and Urban Development, 6(4), pp. 211-228.

BRE, 2003. Construction and Demolition Waste: Good Buildings Guide 57 Part 1. Building Research Establishment, UK

Cha, H. S., Kim, J., \& Han, J. Y. 2009. Identifying and assessing influence factors on improving waste management performance for building construction projects. Journal of Construction Engineering and Management, 135(7), pp. 647-656.

Chen, Z., Li, H. and Wong, C.T., 2002. An application of bar-code system for reducing construction wastes. Automation in Construction, 11(5), pp.521-533.

Cox, R.F., Issa, R.R. a\& Ahrens, D., 2003. Management's perception of key performance indicators for construction. Journal of construction engineering and management, 129(2), pp.142-151.

Creswell, J.W., 2013. Research design: Qualitative, quantitative, and mixed methods approaches, $4^{\text {th }}$ edition. Sage publications.

Dainty, A.R.J., \& Brooke, R.J. 2004. Towards improved construction waste minimisation: A need for improved supply chain integration? Structural Survey, 22(1), pp. 20-29.

DEFRA, 2013. A Rationale for Waste Prevention in England. London: Department for Environment, Food and Rural Affairs (DEFRA).

Del Río Merino, M., Azevedo, I. S. W., \& Gracia, P. I. 2009. Sustainable construction: construction and demolition waste reconsidered. Waste management and research, 28(2), pp. 118-129.

Domingo, N., Osmani, M., \& Price, A. D. 2009. Construction waste minimisation in the UK healthcare industry. IN: Dainty, R.J. (Ed.). Proceedings of the 25th Annual ARCOM Conference, 7-9 September 2009, Albert Hall, Nottingham. Association of Researchers in Construction Management, Vol. 2, pp. 1021-30. 
Ekanayake, L.L., \& Ofori, G. 2004 Building waste assessment score: Design-based tool. Building and Environment, 39(7), pp. 851-861.

Esin, T. \& Cosgun, N., 2007. A study conducted to reduce construction waste generation in Turkey. Building and Environment, 42(4), pp.1667-1674.

Faniran O.O \& Caban G. 1998. Minimizing waste on construction project sites. Engineering, Construction and Architectural Management, 5(2), pp. 182-188.

Faridi, A.S. \& El-Sayegh, S.M., 2006. Significant factors causing delay in the UAE construction industry. Construction Management and Economics, 24(11), pp.11671176.

Fellows, R.F., Langford, D., Newcombe, R. and Urry, S., 2002. Construction management in practice, $2^{\text {nd }}$ edition. John Wiley \& Sons.

Field, A. (2013). Discovering statistics using IBM SPSS statistics, $3^{\text {rd }}$ edition. London: SAGE.

Fincham, J. E. 2008. Response rates and responsiveness for surveys, standards, and the Journal. American Journal of Pharmaceutical Education,72(2),

Forster, G., 2014. Construction Site Studies: Production Administration and Personnel, $2^{\text {nd }}$ edition Oxon: Routledge.

Golob, L. 1992. Site management and construction health and safety. In: Harlow, P. A., The practice of site management. Berkshire: The Chartered Institute of Building.

Gupta, V., 1999. SPSS for Beginners. 1stBooks Library.

Harlow, P.A., 1992. The practice of site management. Berkshire: The Chartered Institute of Building.

Hassan, S. H., Ahzahar, N., Fauzi, M. A., \& Eman, J. 2012. Waste Management Issues in the Northern Region of Malaysia. Procedia-Social and Behavioral Sciences, 42(2012), pp. 175-181.

Hwang, B. G., Thomas, S. R., Haas, C. T., \& Caldas, C. H. 2009. Measuring the impact of rework on construction cost performance. Journal of Construction Engineering and Management, 135(3), 187-198.

Isikdag, U., \& Underwood, J. 2010. Two design patterns for facilitating Building Information Model-based synchronous collaboration. Automation in Construction, 19(5), 544-553.

Jaillon, L., Poon, C.S. \& Chiang, Y.H., 2009. Quantifying the waste reduction potential of using prefabrication in building construction in Hong Kong. Waste management, 29(1), pp.309-320. 
Jingkuang, L. \& Yousong, W., 2011. Establishment and application of performance assessment model of waste management in architectural engineering projects in China. Systems Engineering Procedia, 1, pp.147-155.

Kaming, P.F., Olomolaiye, P.O., Holt, G.D. \& Harris, F.C., 1997. Factors influencing construction time and cost overruns on high-rise projects in Indonesia. Construction Management \& Economics, 15(1), pp.83-94.

Kumaraswamy, M.M. \& Chan, D.W., 1998. Contributors to construction delays. Construction Management \& Economics, 16(1), pp.17-29.

Li, H., Chen, Z. \& Wong, C.T., 2003. Barcode technology for an incentive reward program to reduce construction wastes. Computer-Aided Civil and Infrastructure Engineering, 18(4), pp.313-324.

Long, N.D., Ogunlana, S., Quang, T. \& Lam, K.C., 2004. Large construction projects in developing countries: a case study from Vietnam.International Journal of project management, 22(7), pp.553-561.

Love, P.E. \& Li, H., 2000. Quantifying the causes and costs of rework in construction. Construction Management \& Economics, 18(4), pp.479-490.

Lu, W., \& Yuan, H. 2010. Exploring critical success factors for waste management in construction projects of China. Resources, conservation and recycling, 55(2), pp. 201208.

Lu, W., \& Yuan, H. 2013. Investigating waste reduction potential in the upstream processes of offshore prefabrication construction. Renewable and Sustainable Energy Reviews, 28(2013), pp. 804-811

Mäki, T. \& Kerosuo, H., 2015. Site managers' daily work and the uses of building information modelling in construction site management. Construction Management and Economics, 33(3), pp.163-175.

Marinelli, M., Dolan, M., Spillane, J., \& Konanahalli, A. 2014. Material waste in the Northern Ireland construction industry: On-site management, causes and methods of prevention. In: Raiden, A. B and Aboagye-Nimo, E. (Eds.). Proceedings of 30th Annual ARCOM Conference, 1-3 September 2014, Portsmouth, UK, Association of Researchers in Construction Management, 113-122.

Mustapha, F.H. \& Naoum, S., 1998. Factors influencing the effectiveness of construction site managers. International Journal of Project Management, 16(1), pp.1- 
Nagapan, S., Rahman, I.A., Asmi, A., Memon, A.H, \& Zin, R.M. 2012. Identifying causes of construction waste - Case of central region of Peninsula Malaysia. International Journal of Integrated Engineering, 4(2), pp. 22-28

Nunnally, J.C., \& Bernstein, I.H. 2007. Psychometric Theory, $3^{\text {rd }}$ edition. New York: McGraw-Hill.

Osmani, M., Glass, J. \& Price, A.D., 2008. Architects' perspectives on construction waste reduction by design. Waste Management, 28(7), pp.1147-1158.

Oyedele, L.O., Ajayi, S.O. \& Kadiri, K.O., 2014. Use of recycled products in UK construction industry: An empirical investigation into critical impediments and strategies for improvement. Resources, Conservation and Recycling, 93, pp.23-31.

Oyedele, L.O., Regan, M., Meding, J.V., Ahmed, A., Ebohon, O.J., \& Elnokaly, A. 2013. Reducing waste to landfill in the UK: Identifying impediments and critical solutions. World Journal of Science, Technology and Sustainable Development, 10(2), pp. 131 142.

Poon, C.S., Yu, A.T. \& Jaillon, L., 2004. Reducing building waste at construction sites in Hong Kong. Construction Management and Economics, 22(5), pp.461-470.

Poon, C.S., Yu, A.T.W., \& Ng, L.H. 2001. On-site sorting of construction and demolition waste in Hong Kong. Resources, Conservation and Recycling, 32(2), pp. 157-172.

Saez, P. V., del Río Merino, M., González, A. S. A., \& Porras-Amores, C. 2013. Best practice measures assessment for construction and demolition waste management in building constructions. Resources, Conservation and Recycling, 75(2013), pp. 52-62.

Sanvido, V., Grobler, F., Parfitt, K., Guvenis, M. \& Coyle, M., 1992. Critical success factors for construction projects. Journal of construction engineering and management, 118(1), pp. 94-111.

Shen L.Y, Tam V.W.Y., 2002. Implementation of environmental management in the Hong Kong construction industry. International Journal of Project Management, 20(7), pp. $535-43$.

Solís-Guzmán, J., Marrero, M., Montes-Delgado, M.V. and Ramírez-de-Arellano, A., 2009. A Spanish model for quantification and management of construction waste. Waste Management, 29(9), pp.2542-2548.

Tam, C.M., Zeng, S.X. and Deng, Z.M., 2004. Identifying elements of poor construction safety management in China. Safety Science, 42(7), pp.569-586. 
Tam, V.W.Y. 2008. On the effectiveness in implementing a waste-management-plan method in construction, Waste Management, 28(6), pp. 1072-1080.

Toor, S.U.R. \& Ogunlana, S.O., 2008. Problems causing delays in major construction projects in Thailand. Construction Management and Economics, 26(4), pp.395-408.

Wang, J., Li, Z., \& Tam, V.W.Y. 2014. Critical factors in effective construction waste minimization at the design stage: A Shenzhen case study, China. Resources, Conservation and Recycling, 82(2014), pp. 1-7.

WRAP, (2009a). "Designing out waste: A design team guide for buildings" (online). Available at: http://www.modular.org/marketing/documents/DesigningoutWaste.pdf. [Accessed: $3^{\text {rd }}$ March, 2014]

Yeheyis, M., Hewage, K., Alam, M.S., Eskicioglu, C., \& Sadiq, R. 2013. An overview of construction and demolition waste management in Canada: A lifecycle analysis approach to sustainability. Clean Technologies and Environmental Policy, 15(1), pp. 81 $-91$.

Yuan, H. 2013. Critical management measures contributing to construction waste management: Evidence from construction projects in china. Project Management Journal, 44(4), pp. 101-112. 